\title{
シンポジウム $\mathbf{A}$
}

\section{塵肺および塺肺結核の治療}

\author{
司会蔖肺研究委員会委員脣
}

佐 野 辰 雄 (学研)

\section{1. 司会者のことば}

けい肺措置要綱，けい肺等特別保護法を経て，画期的 な「じん肺法」は35年4月に制定された。「じん肺法」 の学問的基礎は，労働省に設けられた「じん肺研究班」 (昭和30年以後 宝来善次班長) によって築かれたもの であるが，午の班員汇汪とんぞ産業衛生協会の会員であ り，関連学会に重さをなしていた人達であった。

この法律制定までの各方面の努力は；一つの壮観であ ったが，じん肺の診断，治療，予防にわたる広汎で複雑 な問題は，法の施行によって一挙に解決するものではな い。法施行以前よりも, さらに広汎な産衛会員の参加と その強い協力が必要なのである。

産業衛生協会では，この要請に応じて，37年10月に 「じん肺研究委員会（委員長 宝来善次)」を発足させ， 『診断と治療についての研究』をすすめた。この委員会 の経過は，「宝来善次：麼肺研究委員会中間報告，産業医 学 5 (11)」及び「麼肺研究委員会報告書（pp. 1 52） 昭39.4.」にくわしい。

39 年 6 月に発足した第 3 年度の委員会（委員長 佐野 辰雄）では；委員間の討議により，さらに各地方会の経 験豊富なメンバーを充実し，地方会ごとの討議を経て， 全体の討論を行ら形式を採用することになった。39年10 月に行われた関東地方会のコンファレンス，「じん肺及 びじん肺結核の治療」は，その1例である(コンファレ ンス記録 pp. 1〜44)。

このようにすれば，現場の経験，研究がより効果的に 吸収され，研究の現場への浸透がより容易となるからで ある。

39年度テーマは前記のようにしぼられ，さらに具体的 なテーマには，つぎのよらなものがあげられた。

A. じん肺の治療

1. 臇機能改善の方法 2 . 心機能保持法 3. 気
管支炎，肺気腫の治療 4. リハビリテーション

B. じん肺結核の治療

(1) 内科方面

1. 各種塵肺結核の異同之化学療法の避択 2 . 塺 肺結核活動性の定義 3 . 抗結核剂予防投与の効果

4. 塺肺結核の混合感染 5 . その他

(2) 外科方面

1. 塺肺結核の手術適応，手術手技 2 . 手術之内 科療法の関係 3. その他

この39年度委員会の成果が，今回のシンポジウムの内 容になるわけである。シンポジウムとしては，演者の数 は多いが，これは各地方，各産業の特色が明らかにされ ることが研究全体にとって有利と判断したからである。

目ざすところは，各地方，各委員の研究を精選して， 近年の進歩を会員につたえ，から，この中から今後の問 題点を摘出することにある。

会員諸氏の事実に基づくきびしい討論を期待してやま ない。

\section{2. 炭鉱の塵肺及び塵肺結核}

\section{豊福 豊（岩見沢労災）}

本邦に和いては，金属鉱山，穼業，石工等の粉塵職歴 を有するものの塵肺及び塵肺結核に関する研究は，かな り詳細に解明されているが，最も多数の就慈者を擁して いる石炭鉱山の塵肺及び塵肺結核について，ことにその 病理解剖所見については，まとまった研究報告が行われ ていない。昭和初年, 有馬英二, 白川栨治両氏によっ て，その臨床所見及びレントゲン所見について，貴重な 業績がなされたのであるが，遺憾なことに，病理所見に ついては汪とんど触れられていない。爾来，今日まで， 純炭鉱塵肺の系統的研究悓のがされて，今日に至って いる実情である。

岩見沢労災病院開設以来，今日まで10年間にお和る鷹 